\title{
103 浮体式多自由度波力発電装置の粒子法を用いた挙動解析
}

\author{
Behavior Analysis of Floating MDOF Wave Power Generation using Particle Method
}

$\begin{array}{rllll}\text { O学 安嶋 魁（茨城大） } & \text { 正 田中 伸厚（茨城大） } \\ \text { 学 高山 剛 (茨城大) } & \text { 学 鈴木 健司（茨城大） }\end{array}$

\author{
Kai AJIMA, Nobuatu TANAKA, Gou TAKAYAMA, Kenji SUZUKI \\ Ibaraki University, 4-12-1, Nakanarusawa, Hitachi, Ibaraki
}

\begin{abstract}
Recently, environment problems due to the use of fossil fuel, such as global warming, climate change, air pollution, acid rain and many others, are becoming serious. To solve the problem, alternative renewable energy is required. In this paper, we focuses on the effective use of ocean power and have developed a compact, low-cost but flexible floating buoy to generate electric power from ocean wave. In order to optimize the design, we perform fluid-structure interaction analyses to consider the buoy motion without experiments. However, it was difficult to achieve the optimization for the commercial code, ANSYS, because there are many restrictions in ANSYS due to its mesh-based algorithm. Therefore, we originally develop a particle(SPH)-based analysis code.
\end{abstract}

Key Words : wave-power, particle method, SPH

\section{1. 緒言}

今日，地球上では温暖化，気候変動，大気污染，酸性雨な ぞの環境問題が問題になっている.これらの問題は二酸化炭 素, 硫黄酸化物, 窒素酸化物などの排出が原因となっており, これら物質の排出の元を辿ると化石燃料の使用がある. そこ で近年注目されているのが再生可能エネルギーである. 再生 可能エネルギーは化石燃料と比べ資源量が豊富であり, 環境 負荷が少ない。ここでは再生可能エネルギーのうちの海洋エ ネルギーについて注目する. 現在, 地球表面は約 $71 \%$ が海で 覆われており海洋エネルギーの資源量は豊富である.また, その中の波力発電に必要な波力エネルギーは世界全体で $8000 \sim 80000 \mathrm{TWh} /$ 年あり日本の 1 年間の電力消費量 1083TWh/年の約 7.4 74 倍である. それに加え, 日本は四方 が海に囲まれているため, 海洋エネルギーは日本においても 今後期待できるエネルギー資源であると考えられる.

本研究では粒子法(SPH 法)を用いて波による発電装置の挙 動解析を行い，最適化することを目的とする.

\section{2. 発電装置概要}

発電装置の形は四面体であり, 各辺(6 辺)にコイルと磁石 が付いており，装置が動くことにより磁石とコイルの相対運 動が生じ発電するという構造になっている. なお，この装置 の実験は本研究室の鈴木が行った.

\section{3. 解析手法}

解析は ANSYS および粒子法(SPH 法)を用いて行った。 3-1 ANSYS 本解析は初めに ANSYS FLUENT の VOF モデ ルとユーザー定義関数(UDF)を用いて行った. VOF モデルで は, 一組の運動方程式の解を求めるとともに領域全体におけ る各流体の体積分率を追跡することによって, 複数の非混合 流体に関するモデルを作成できる. 主な適用対象としては, 噴射分散の予測, 液体中の大気泡の挙動, ダム決壊後の液体 の挙動，気液界面の定常・非定常追跡がある[1]. UDF とは ユーザー自身がプログラムする関数である. 物体の質量や慣 性モーメントなどを定義でき, ANSYS FLUENT に読み込ま せることで解析の幅を広げることができる.

本解析は実験との比較のために水槽の体系を模擬している. 体系の大きさは幅: $0.75 \mathrm{~m} \times$ 奥行き: $0.187 \mathrm{~m} \times$ 高さ: $0.3 \mathrm{~m}$ である. 実験と波の波形，波高をそろえるために右側に $5 \mathrm{~mm}$ の壁を 加えた. この中に 1 辺 $8 \mathrm{~cm}$ の四面体があることを想定し，水
と空気の混相流における四面体の挙動の解析を行う．Fig.1 に解析体系の図を示す．なお，四面体の質量は $48.3 \mathrm{~g}(\rho$ $\left.=800\left[\mathrm{~kg} / \mathrm{m}^{3}\right]\right)$, 慣性モーメントは $2.2 \times 10^{-5}\left[\mathrm{kgm}^{2}\right]$ の解析を行 った.

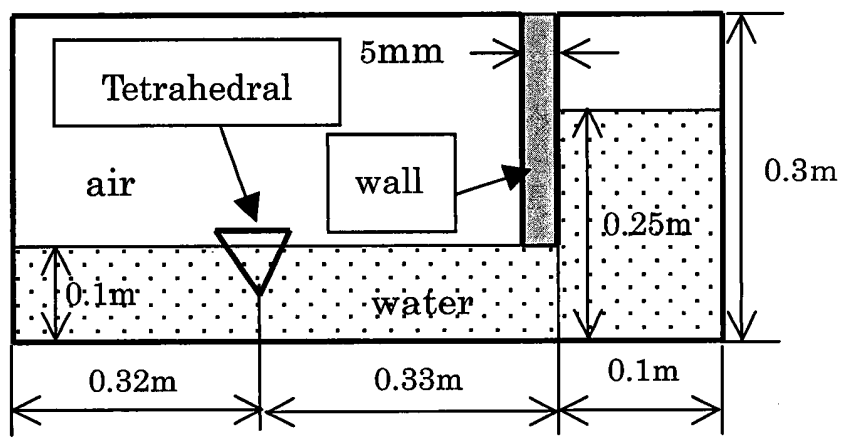

Fig.1 Analysis system(ANSYS)

シミュレーションと実験の比較の図を Fig.2, Fig.3に示し, $48.3 \mathrm{~g}$ の場合の左右方向の変位, 奥行き方向軸に関する角度 の比較グラフを Fig.4 に示す. 波の波形, 波高, 周期および ブイの変位はシミュレーションと実験でかなり近い結果が 確認できた. 一方で Fig.4 より，角度はシミュレーションと 実験で差があることが確認できる.これは慣性モーメントに 差があるためだと考えられる。

ANSYS では，本解析のように計算が最後まで流れること はまれで, 密度や慣性モーメントが小さい場合は計算が発散 してしまい解析できない。これは，ANSYS がメッシュに基 づく手法であり，メッシュ生成が困難となる問題（たとえば ブイと壁面が接触するような場合）では解析が不可能なため である. 以上のことより ANSYS では解析条件に制限があり， このような連成解析には適していない.

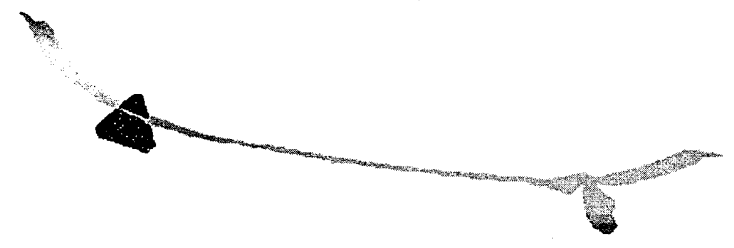

Fig.2 $\quad 48.3 \mathrm{~g}$ (Analysis) 


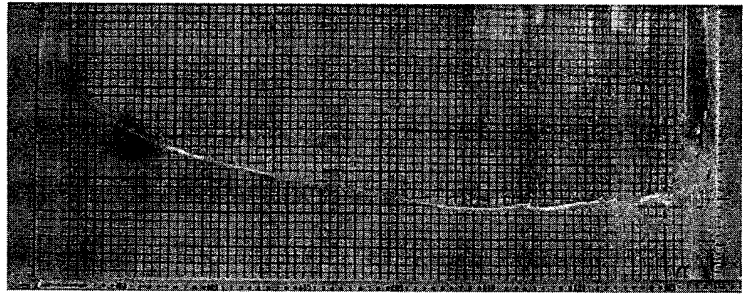

Fig.3 $48.3 \mathrm{~g}$ (Experiment)

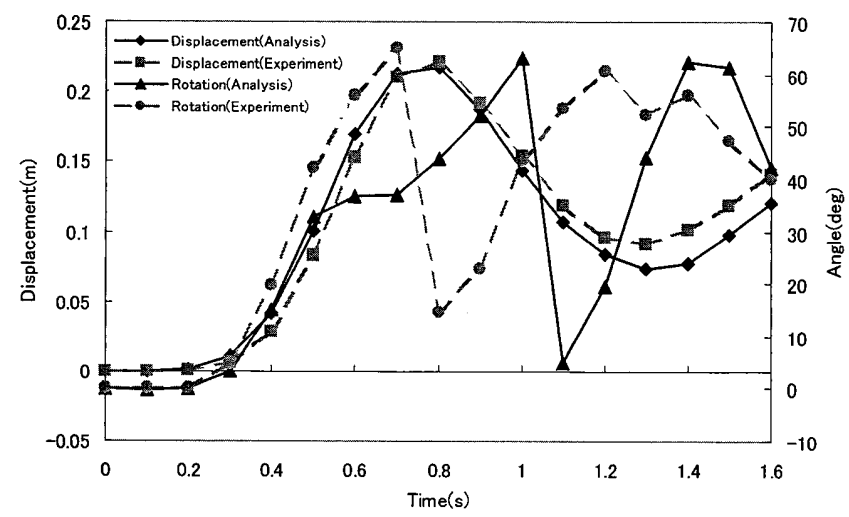

Fig.4 48.3g(Displacement and Angle)

3-2 SPH 法 SPH 法は流体を粒子の集合体として近似的に 表す. 流体の支配方程式を粒子間相互作用モデルで置き換え， 各粒子が持つ速度などの変数の変化を粒子間相互作用に基 づいて計算する. そして, カーネルと呼ばれる重み関数 Wを 導入し，粒子のもつ物理量を周囲に重み付けすることで, 評 価点の物理量を内挿する.すなおち, 粒子はカーネルで表さ れる物理量の分布を持っており，それらの重ね合わせにより

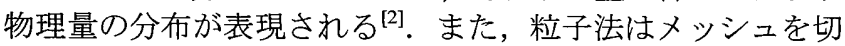
る必要がないため複雑な変形の解析にも対応できる．任意の 位置 $\mathrm{r}$ における物理量 $\mathrm{A}(\mathrm{r})$ の式を式(1)に示す.

$$
A(r)=\int A\left(r^{\prime}\right) W\left(r-r^{\prime}, h\right) d r^{\prime}
$$

ここで W(r, h)はカーネルを表し, h はカーネルの影響半径 を表す。また，流体を $\mathrm{N}$ 個の体積要素に分割すると式(2)を 得る.

$$
A(\mathbf{r})=\sum_{j=1}^{N} m_{j} \frac{A_{j}}{\rho_{j}} W\left(\mathbf{r}-\mathbf{r}_{j}, h\right)
$$

ここで, $m_{\mathrm{j},} \mathrm{A}_{\mathrm{j}}, \rho_{\mathrm{j}}$ はそれぞれ粒子 $\mathrm{j}$ の質量, 物理量, 密 度である.また, Navier-Stokes の式は以下のように表される。

$$
\frac{D \mathbf{v}_{i}}{D t}=f-\sum_{j=1}^{N} m_{j}\left(\frac{p_{i}}{\rho_{i}^{2}}+\frac{p_{j}}{\rho_{j}^{2}}+\Pi_{i j}\right) \nabla W\left(\mathbf{r}_{i}-\mathbf{r}_{j}, h\right)
$$

ここで $\mathrm{i}, \mathrm{j}$ は粒子の番号, $\mathrm{f}$ は外力を示し，人口粘性Пは 式(5)を用いる.

$$
\Pi_{i j}=-\frac{2 \zeta}{\rho_{i} \rho_{j}} \frac{\mathbf{v}_{i j} \cdot \mathbf{r}_{i j}}{\mathbf{r}_{i j}^{2}+\left(0.01 h^{2}\right)^{2}}
$$

ここでらは粘性の強さを表すパラメータである.

密度 $\rho$, 相詨圧力 $\mathrm{P}$ は以下の式[3]で表される。

$$
\begin{aligned}
& \rho_{i}=\sum_{j=1}^{N} m_{j} W\left(\mathbf{r}_{i}-\mathbf{r}_{j}, h\right) \\
& P_{i}=B\left\{\left(\frac{\rho_{i}}{\rho_{0}}\right)^{\gamma}-1\right\}
\end{aligned}
$$

ここで $\mathrm{B}$ は基準圧力， $\rho_{0}$ は密度の基準量である.

現段階で粒子法の解析コードは開発中のため,ここではダ ムブレークの解析を示す. 解析体系を Fig. 5 に示す. 粒子の 大きさは $5 \mathrm{~mm}$ とし,壁には 4 列粒子を配置し slip 壁とした.
時間刻みは $1 \times 10^{-5}[\mathrm{~s}]$ で解析を行った。また，式(6)における $\gamma$ は 22 とした。

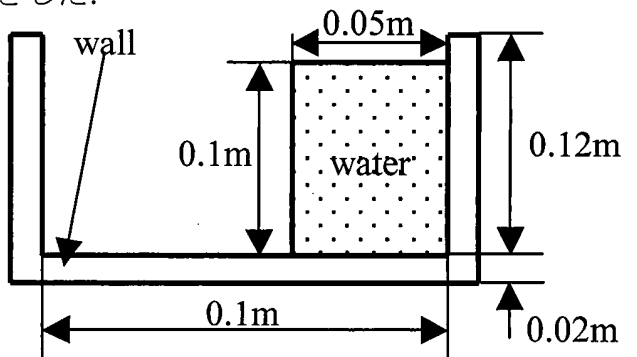

Fig.5 Analysis system(SPH)

解析結果を Fig.6 に示す. Fig.6(a)では水の静水圧の分布が 下から上に低くなっていかず，下面の圧力が低くなってしま っている.このことから圧力分布の結果が正しい值ではない と考えられる.また，Fig.6(b)では水粒子の間隔が一部不自然 であることが確認できる.これらは式(6)の $\gamma$ の值が大きすぎ るために出た影響だと考えられる. また標準的な $\gamma$ の值であ る 7 を入れた場合, 全ての水粒子が壁をすり抜けてしまいダ ムブレークが解析できなかった. さらに Fig.6(c), (d)でも多 くの水粒子が壁からすり抜けることが確認された。これは壁 粒子の圧力が低いために水粒子を押し返すことができない ためであり, 式(5)の密度を求める計算, または式(6)の圧力を 求める計算で問題がある可能性が考えられる.さらに，水柱 の最左端の列の粒子だけ不自然な速度ベクトルが出た.この 点も今後検討する余地があると考えられる。

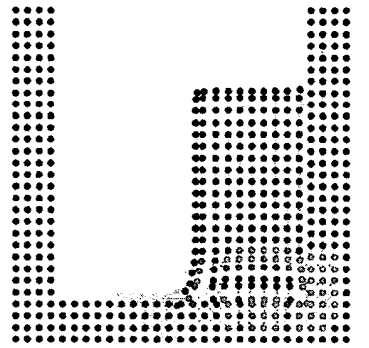

(a) $\mathrm{t}=0.04[\mathrm{~s}](4000 \mathrm{step})$

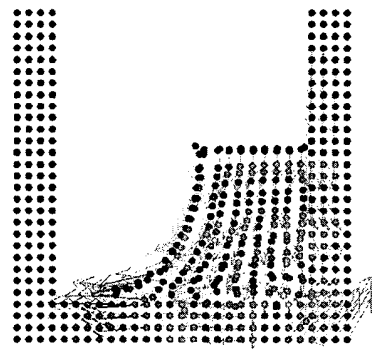

(b) $\mathrm{t}=0.08[\mathrm{~s}](8000$ step)

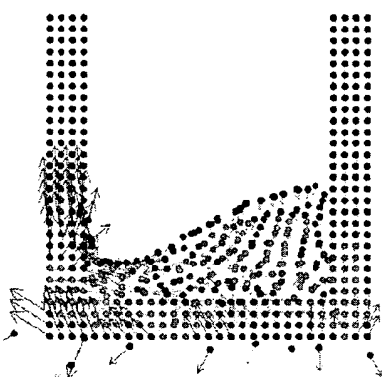

(c) $\mathrm{t}=0.12[\mathrm{~s}](12000$ step $)$

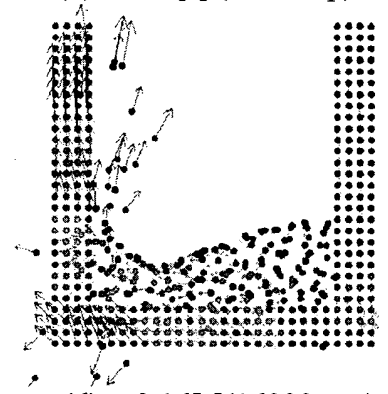

(d) $\mathrm{t}=0.16[\mathrm{~s}](16000 \mathrm{step})$
Fig. 6 distribution of particle position, velocity and pressure

\section{4.まとめ}

本研究で用いている粒子法コードは現在開発中であり, 修 正すべき点が多く存在することが改めて確認された。 また目 標である浮体物の解析のために, 構造体を定義する新たなア ルゴリズムを組み込む必要もある. これらの点を含め, 今後 は更なる検討を重ねていく予定である.

\section{参考文献}

[1]ANSYS FLUENT 12.0 理論ガイド, URL: http://www2.ansys.jp

[2]高野龍雄 : 茨城大学修士論文(2005)

[3]G.R.Liu, M.B.Liu: Smoothed Particle Hydrodynamics, World Scientific(2005), 40-137 